Relations industrielles

Industrial Relations

\title{
Wright, Christopher, The Management of Labour: A History of Australian Employers
}

Peter Waring

Volume 54, numéro 1, 1999

Relations industrielles et nouveaux systèmes productifs

Industrial Relations in the New Workplace

URI : https://id.erudit.org/iderudit/051229ar

DOI : https://doi.org/10.7202/051229ar

Aller au sommaire du numéro

Éditeur(s)

Département des relations industrielles de l'Université Laval

ISSN

0034-379X (imprimé)

1703-8138 (numérique)

Découvrir la revue

Citer ce compte rendu

Waring, P. (1999). Compte rendu de [Wright, Christopher, The Management of Labour: A History of Australian Employers]. Relations industrielles / Industrial Relations, 54(1), 205-207. https://doi.org/10.7202/051229ar

Tous droits réservés @ C Département des relations industrielles de l'Universite Laval, 1999
Ce document est protégé par la loi sur le droit d'auteur. L'utilisation des services d'Érudit (y compris la reproduction) est assujettie à sa politique d'utilisation que vous pouvez consulter en ligne.

https://apropos.erudit.org/fr/usagers/politique-dutilisation/ 
to demonstrate that their sample is representative. This may be especially so given the design of the present survey, which was billed to potential respondents as "a survey into the role of direct participation in organizational change" which "will take less than 30 minutes." My experience is that employers without direct participation schemes or for whom such schemes have proven ineffective may be less likely to invest the time needed to respond to a survey of this length, believing the survey not to be applicable to their workplace or relevant to their interests.

As is often the case with survey data, the data also do not always speak for themselves. Rather, much depends on how they are analyzed and interpreted. While the results are clearly presented and well-argued, the conclusions drawn by the authors may go somewhat beyond what the data show. For example, the finding that direct participation schemes are often associated with layoffs may say less about these schemes than about the economic conditions and institutional context under which they are often implemented. It does not suggest an inherent association.
In view of these limitations, both the results and conclusions should be interpreted with some caution. Yet the authors' findings seem to reinforce what is now becoming a common theme in the literature: that the adoption of workplace innovations is not inherently consistent with the interests of either employers or employees. Rather, much may depend not only on the workplace context, but also on the wider institutional and social context. Thus, the optimistic view that direct participation represents a "voluntaristic" alternative to state involvement in labour markets, one which enhances both equity and efficiency if only employers can be convinced to take it seriously and various barriers are removed, may not be justified. Rather, there may be need of more basic institutional reforms. Ideally such reforms would induce employers to adopt the "high skill, high pay" work arrangements which many have associated with direct participation. But if not, they should at minimum seek a better balance between equity and efficiency considerations than is presently characteristic of many western nations.

JOHN GODARD

University of Manitoba

\section{The Management of Labour: A History of Australian Employers}

by Christopher WRIGHT, Melbourne: Oxford University Press, 1995, 314 p., ISBN 0-19-553549-9.

It is a privilege to review such an insightful and timely contribution to contemporary debates concerning the nature of employer strategy. Chris Wright's The Management of Labour: A History of Australian Employers should be perceived as an important text, not simply as an elegant historical account of Australian employers, but for the challenge it represents to traditional orthodoxy. The book offers a forceful and cogent argument against the widely held view that employers 'muddle through' the management of industrial relations in reactive and uncer- tain fashion. According to Wright, not only does the historical evidence of Australian employers lend support to the notion of strategic choice but that such strategic choices made within the context of specialized employee management practices are nothing new.

As Wright argues, in general, the overwhelming focus of industrial relations discourse over the last decade on innovation in the management of human resources and industrial relations has occurred without reference to historical developments. Contemporary literature concerning 'soft' 
human resource management practices such as methods of employee consultation and participation, culture management and sophisticated methods of selection and appraisal have often been characterized as revelations in the field of management. This book demonstrates that these practices should be regarded as continuation rather than innovation.

Wright constructs his arguments by drawing upon an original and sophisticated synthesis of corporate records and the files and archives of management consultants, government departments, and trade unions. However, the richest sources of data are the result of extensive interviews conducted with "former personnel and industrial relations officers, methods engineers, work study analysts, works managers, supervisors, management consultants and trade union officials". According to Wright, these interviews also served a useful purpose in exposing the gap between the rhetoric contained in management policy and the reality of shopfloor experience. In addition, the author occasionally delights and amuses his readers by presenting 'pearls of wisdom' from early twentieth century management journals. Consider for example the following advice:

"The worker is restless, and the industrial scene must be approached with the science and methods of an advertising and public relations campaign. What is trying to be sold is that the company is a good employer, is reasonable. is generous and that it cares for its employees" (p. 58).

Whilst the book has an explicit Australian orientation, it should procure a wider appeal than simply those with an interest in the management strategies of Australian employers. Discussion of the management practices of transnational corporations, such as Goodyear, British Motor Corporation and British Tube Mills operating in Australia in the twentieth century, should stimulate the interest of a broader audience.

The book itself is structured around three major parts, each examining a sepa- rate historical period. Part one considers the period from 1870 to 1930 ; part two, the period from 1940 to the 1960 s and the third part analyses the period from the 1970 s to the early 1990 s.

In part one, the book describes the formative years of employer strategy in Australia, from primitive labour process techniques such as simple control to more systematic methods of labour management including early experimentation with welfarism. However, the book's unique observations are never made in isolation from the economic, political and institutional context as it considers the impact of environmental factors on management's approach to the labour problem.

In describing the method of simple control, the author draws on excellent examples at early Australian steel plants where supervisors were committed to the 'driving method' of supervision. This form of simple control used a combination of bullying, abuse, close supervision and the ever present fear of arbitrary dismissal to drive production. High levels of unemployment also assured the relative success of simple control as did the maintenance of 'black lists' which held the names of unionists and potential 'troublemakers' that were not to be employed.

This description of simple control is juxtaposed with early experiments in paternalistic welfarism. The best known examples of welfarism occurred at a large Australian department store which still prospers today. However, the author makes it clear that these early experiments with welfarism were not solely driven by philanthropy but in the sincere belief that maintaining a happy and healthy workforce were the cornerstones of good business practice. The author cites an early management journal which clearly followed this trend with enthusiasm and is worth reciting here:

"the kind of welfare work carried out by these admirable companies is calculated to do more to refute and destroy communism than all the propagandist literature ever published. Nothing could be 
more productive of goodwill between employers and employees... Employers of labour are too apt to ignore the human side of industry, too apt to treat employees not as human beings. frequently keen of intellect and emotionally sensitive, but as mere tools for the production of values. That is bad morals, bad psychology and in the end, bad business" (p. 22).

The book though is also at pains to ensure that the reader is not left with the mistaken impression that welfarism dominated managerial practice in the early twentieth century. Indeed, it cites a 1931 survey which found that only seventy-six large firms had experimented with welfarism. An additional dimension of this part of the book is the way in which it usefully parallels the discussion of management strategies with an examination of the rise of trade unionism and employer associations.

The second part of the book examines the growth in bureaucratic work organization and the peculiar labour problems faced by management in an economy on a war footing. With permanent reductions in unemployment (both during and post-World War Two) driven by solid periods of economic growth, some managers were forced to discard traditional and overtly oppressive control techniques and began to develop relatively sophisticated recruitment and selection techniques, in addition to specific training, communication and reward management policies. The task of developing and administering these policies was the task of newly appointed personnel or welfare officers as they were sometimes described. However, the author cautiously argues that whilst the bureaucratization of work and the rise of personnel function were prevalent in the post-war years, employers also sought to tighten their control over labour and hence output, through the application of scientific management techniques.
The final part of the book details the economic crisis brought about by the 1970 s supply side shocks. The coexistence of stubborn inflation and continuing high unemployment in the early $1980 \mathrm{~s}$ was the catalyst for a price and incomes agreement between the Federal Labor government and the peak Australian trade union body, the ACTU. The agreement known as the Accord, delivered reductions in real wages to employers, whilst the government simultaneously placed industry under enormous pressure by prizing open the economy to international competition. It is within this context of rapid change that the author describes a period of management experimentation. As the author notes, this experimentation included: employee participation schemes; work reorganization and organizational redesign, downsizing, delayering, just-in-time, TQM, quality assurance and culture management. The book, significantly, does not merely attempt to observe the incidence of these practices but, importantly, traces the agents of their diffusion. The book also weighs into the personnel/HRM debate, persuasively arguing that history dictates that the differences between the two should not be overstated.

Chris Wright's, The Management of Labour: A History of Australian Employers is an outstanding and significant piece of scholarship. The book's original research and unique observations of twentieth century labour process strategies make it compelling reading. The book exerts substantial intellectual authority in the literature on employer strategy and deserves to be regarded as an invaluable contribution to contemporary debates.

PETER WARING

University of Newcastle Australia 